\title{
Pectinesterase, Polygalacturonase, and $\beta$-galactosidase during Softening of Ethylene-treated Kiwifruit
}

\author{
Teresa F. Wegrzyn and Elspeth A. MacRae \\ Department of Scientific and Industrial Research, Fruit and Trees, \\ Private Bag, Auckland I, New Zealand
}

Additional index words. ethylene, fruit softening, cell wall, Actinidia deliciosa

Abstract. The activities of several cell wall-associated enzymes of the outer pericarp were assayed during softening of kiwifruit [Actinidia deliciosa (A. Chev.) C.F. Liang et A.R. Ferguson var. deliciosa cv. Hayward] treated with ethylene. The activity of polygalacturonase (EC 3.2.1.15) increased slightly during fruit softening, while $\beta$ galactosidase (EC 3.2.1.23) activity remained constant. Salt-extracted pectinesterase (EC 3.1.1.11) activity increased during ethylene treatment, then dropped rapidly to low levels as fruit softened. Residual pectinesterase activity, extracted after digestion of the cell wall pellet with a fungal enzyme mix, decreased on softening. The rapid softening of kiwifruit in response to ethylene treatment may be initiated by an induction of pectinesterase activity, causing increased de-esterification of cell wall pectins, followed by degradation of solubilized pectin.

Mature kiwifruit show a rapid drop in firmness after harvest until the fruit reach a firmness of $\approx 25 \mathrm{~N}(2.5 \mathrm{kgf})$. The rate of softening then slows considerably. If the fruit are exposed to ethylene, the rate of softening of fruit increases, and there is less difference between individual fruit for firmness and soluble solids concentration (SSC) (Lallu et al., 1989). The outer pericarp of the fruit softens more rapidly than the core of the fruit (MacRae et al., 1989), and there is a difference in the timing of chemical changes in the cell walls of the different tissues (Redgwell et al., 1990). In the early stages of kiwifruit softening in response to ethylene, the most obvious changes in the cell wall components are swelling of the cell wall and loss of galactose from pectic polymers (Redgwell et al., 1990; 1991). De-esterification of pectins and some breakdown of middle lamella pectic polymers may also be occurring. By the time kiwifruit have reached a firmness of $6 \mathrm{~N}(0.6 \mathrm{kgf})$, pectic polymers have become smaller, and de-esterification has clearly taken place (Redgwell et al., 1991).

Previous studies on kiwifruit have focused on changes in pectin methylesterase (PE; EC 3.1.1.11) and polygalacturonase (PG) during fruit development (Matsui and Kitagawa, 1988), in whole ripe fruit (Fuke and Matsuoka, 1984; Giovane et al., 1990; Soda et al., 1986), or in kiwifruit after slicing (Varoquaux et al., 1990). Ogawa et al. (1990) measured $\beta$-galactosidase ( $\beta$-gal) activity in kiwifruit during growth and maturation on

Received for publication 5 Aug. 1991. Accepted for publication 4 Mar. 1992. We thank J. Harman for advice on techniques, and D.R.K. Harding and J. Gibson (Separation Science Unit, Massey Univ., Palmerston North, New Zealand) for manufacture of leupeptin. The cost of publishing this paper was defrayed in part by the payment of page charges. Under postal regulations, this paper therefore must be hereby marked advertisement solely to indicate this fact. of $8.2 \%$ SSC from the Dept. of Scientific and Industrial Research (DSIR) Research Orchard at Te Puke, New Zealand, then treated within $6 \mathrm{~h}$ with ethylene (16 h, 1000 $\mu \mathrm{l} \cdot$ liter $\left.^{-1}, 20 \mathrm{C}\right)$ and ripened at 20C in trays provided with polyethylene liners. Samples were taken before ethylene treatment and at 1,2 , and 5 days after treatment. As the 1988 fruit were already quite soft at the time of the first sampling, ethylene dosage and sampling times were altered for the following season. In 1989, fruit from the DSIR Research Orchard at Kumeu, New Zealand, was harvested at $7.2 \% \mathrm{SSC}$, then treated and rip ened as for 1988 fruit, except that ethylene treatment was for $18 \mathrm{~h}$ at $100 \mu \mathrm{l} \cdot$ liter $^{-1}$, and fruit samples were also taken immediately after ethylene treatment and at 10 days after harvest.

In both years, five replicates were made at each sample time, comprising the outer pericarp of two fruit (1988) or three fruit (1989). Before sampling, fruit firmness was measured for each fruit using a handheld penetrometer (Lallu et al., 1989). Samples were frozen immediately in liquid $\mathrm{N}$ and stored at $-80 \mathrm{C}$. All extraction steps were carried out at $4 \mathrm{C}$, and all assays were carried out at 30C.

Outer pericarp cell wall material was extracted by a modification of the method of Jen and Robinson (1984). About $15 \mathrm{~g}$ of frozen sample was blended to a powder with liquid $\mathrm{N}$ in a Waring blender or ground in a mortar. The powder was weighed without thawing and blended for $1 \mathrm{~min}$ with $50 \mathrm{ml}$ of 5\% polyethylene glycol 6000 (PEG, BDH) in distilled water containing 1 ng partially purified leupeptin/ml (Separation Science

In 1988, fruit were harvested at a maturity

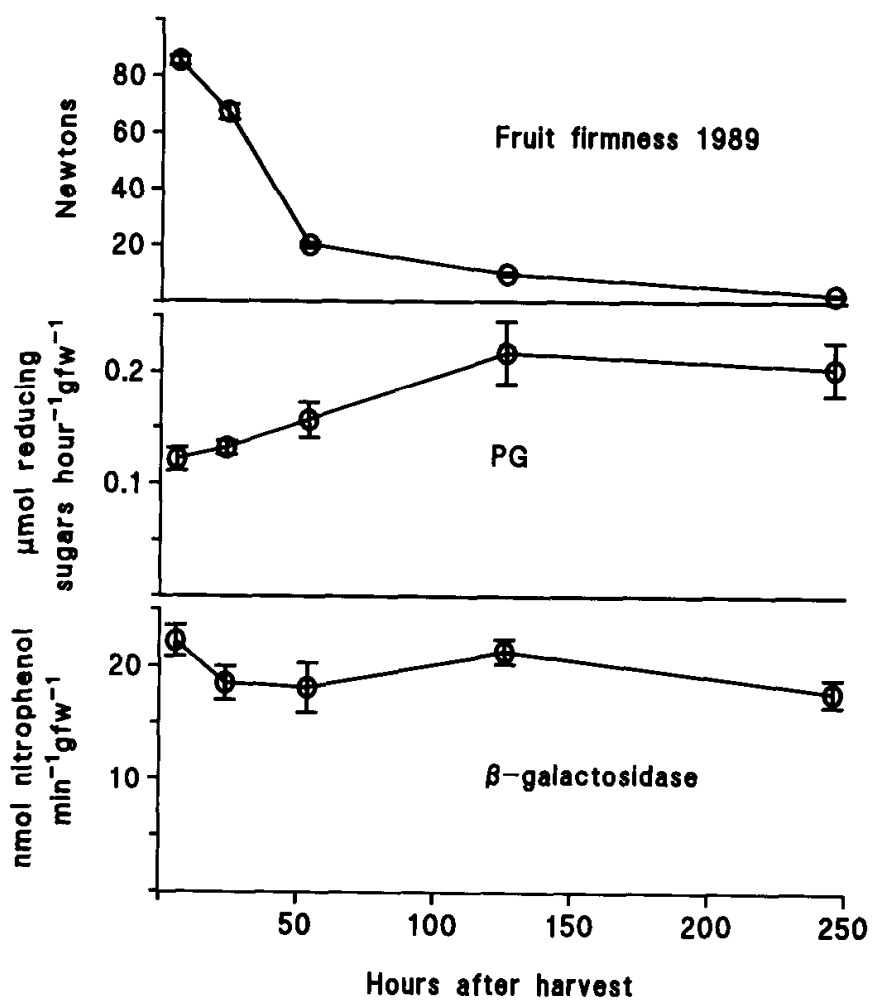

Fig. 1. Changes in fruit firmness and activity of polygalacturonase and $\beta$-galactosidase in kiwifruit after harvest in 1989. All results are presented with SEM. 

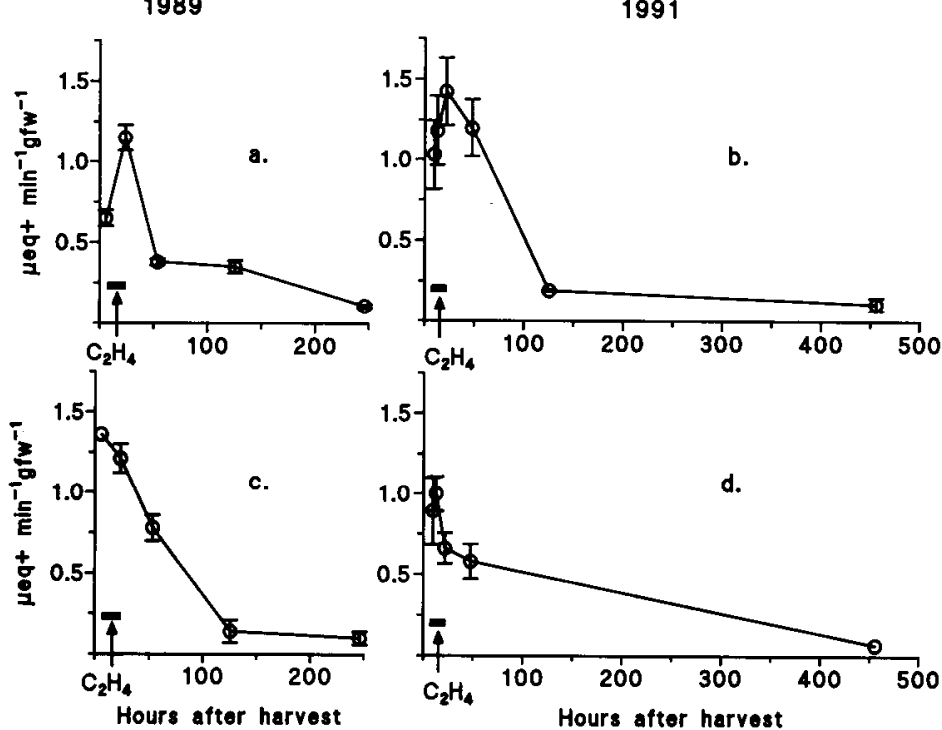

Fig. 2. Salt-extracted (a and b) and digest-extracted (c and d) pectinesterase activity in kiwifruit after harvest in 1989 and 1991. All results are presented with SEM.

Table 1. Changes in fruit firmness in kiwifruit after harvest in 1991. Fruit treated with ethylene (+) were exposed to $100 \mu \mathrm{l} \cdot$ liter $^{-1}$ for $15 \mathrm{~h}$ starting $7 \mathrm{~h}$ after harvest. Data are means of 20 fruit \pm SEM.

\begin{tabular}{lrrrrrrr}
\hline & \multicolumn{7}{c}{ Time after harvest (h) } \\
\cline { 2 - 8 } Ethylene & \multicolumn{1}{c}{ 0 } & 10 & 13 & 22 & 48 & 120 & 456 \\
\hline \multicolumn{7}{c}{ Fruit firmness $(N)$} \\
+ & 83 & 79 & 74 & 69 & 51 & 49 & 5 \\
SEM & 2 & 1 & 1 & 2 & 2 & 2 & 2 \\
- & 83 & $\ldots-$. &.-- & 81 & $\ldots$ &.-- & $\ldots$ \\
SEM & 2 & $\ldots$ & $\ldots$ & 2 & $\ldots$ & $\ldots$ & $\ldots$ \\
\hline
\end{tabular}

Unit, Massey Univ.), which was added to inhibit the protease actinidin (EC 3.4.22.14) (Soda et al., 1986). The homogenate was centrifuged for $30 \mathrm{~min}$ at $16,000 \times \mathrm{g}$. For PG extractions, the pellet was given a second wash with 1.5 volume of 5\% PEG for 10 min and centrifuged again. The pellet was resuspended with stirring for $10 \mathrm{~min}$ in 25 $\mathrm{ml}$ of $1.25 \mathrm{M} \mathrm{NaCl}, 20 \mathrm{~mm}$ EDTA, $5 \mathrm{ng}$ leupeptin/ml, then the $\mathrm{pH}$ was adjusted from $\mathrm{pH} \approx 3.7$ to $\mathrm{pH} 6.5$ with $\mathrm{NaOH}$ and stirred for $45 \mathrm{~min}$. The solution was centrifuged at $16,000 \times \mathrm{g}$ for $30 \mathrm{~min}$. A further $5 \mathrm{ng}$ leupeptin/ml was added to the salt-extracted supernatant before overnight dialysis against 1 liter of $100 \mathrm{~mm} \mathrm{NaCl}, \mathrm{pH}$ 6.5. After centrifugation of the dialysate at $16,000 \times \mathrm{g}$ for 20 min, the supernatant was assayed for PG, $\mathrm{PE}$, and $\beta$ - gal activity.

Residual pectinesterase was extracted by stirring the pellet remaining after salt extraction for $1 \mathrm{~h}$ at room temperature with $20 \mathrm{ml}$ of $1 \%$ cellulase (EC 3.2.1.4) (Sigma), $1 \%$ pectinase (EC 3.2.1.15) (Sigma) in $1 \mathrm{M}$ sodium citrate, and pH 5.5 (Wicker et al., 1988). After centrifugation at $12,000 \times \mathrm{g}$ for $20 \mathrm{~min}$, the supernatant was dialyzed overnight against distilled water. The digestion mix was dialyzed for use as a control.

$\mathrm{PE}$ activity was determined by titrating a $1 \%$ citrus pectin solution containing $1: 10(\mathrm{v} /$ v) of enzyme extract with $10 \mathrm{~mm} \mathrm{NaOH}$ to maintain the $\mathrm{pH}$ at 7.5 (Rouse and Atkins, 1955). For PG, 1 to $5 \mathrm{ml}$ of enzyme extract was assayed in $0.25 \%$ polygalacturonic acid, $50 \mathrm{~mm}$ sodium acetate, $5 \%$ glycerol, and 5 ng leupeptin $/ \mathrm{ml}$. Aliquots of $0.4 \mathrm{ml}$ were measured for reducing sugars by the cyanoacetamide method (Gross, 1982). For $\beta-$ gal, $0.75 \mathrm{ml}$ of enzyme extract was added to $2.6 \mathrm{ml}$ of $75 \mathrm{~mm}$ phosphate/citrate buffer, $\mathrm{pH} 5.0$, and $60 \mu \mathrm{g} \cdot \mathrm{ml}^{-1} p$ - nitrophenol- $\beta$ - D galactopyranoside (Sigma). Aliquots of 0.1 $\mathrm{ml}$ were pipetted into $0.2 \mathrm{ml}$ of $200 \mathrm{~mm}$ sodium carbonate and $\mathrm{A}_{400}$ recorded. No $\beta-$ gal activity was recovered from the PEG supernatant. The activity was inhibited $90 \%$ by $1 \mathrm{~mm}$ D-galacturonic acid- $\gamma$-lactone (Pressey, 1983). All assays were tested with boiled enzyme as controls.

Protein levels were estimated using the modified Lowry method of Perbal (1988), after precipitation of the protein with $0.15 \%$ deoxycholate and 7.2\% trichloroacetic acid. Data are presented on a fresh-weight basis, and all results were similar to those calculated on a protein basis.

As kiwifruit firmness decreased from 80 to $10 \mathrm{~N}, \mathrm{PG}$ activity increased steadily in 1988 (data not shown) and 1989 (Fig. 1). Co-extraction of 1989 samples taken at 24 and 126 $h$ after harvest showed no inhibition of PG activity. Maximum PG activity in crude extract was similar to that obtained by Soda et al. (1986) for partially purified PG from whole kiwifruit but lower than that measured by Matsui and Kitagawa (1988) for kiwifruit during development. The increase we obtained was in the same range as that in PG reported for sweet pepper (Capsicum annuит L.) using a similar extraction protocol (Jen and Robinson, 1984) and avocado (Persea americana Mill.) (Awad and Young, 1979). However, it is still low by comparison with tomato (Lycopersicon esculentum Mill.), which shows a dramatic rise in PG activity during the climacteric (Grierson and Tucker, 1983). The increase noted in kiwifruit PG activity precedes both a decrease in the size of pectic polymers that are its presumed substrate in vivo (Redgwell et al., 1991) and the loss of middle lamella material seen in ultrastructural studies (Hallett et al., 1992).

There was no significant change in B-gal activity as fruit softened in 1988 or in 1989 (Fig. 1). Extracted $\beta$ - gal activity shows no relationship to the significant loss of galactose from the cell wall in vivo (Redgwell et al., 1990), although any increase in activity of active isozymes may be masked in the crude extract (Pressey, 1983) which, in our case, is likely to have included plastid $\beta-$ gal activity. Ogawa et al. (1990) found a 4- to 5 -fold increase in $\beta$ - gal activity and a 10fold increase in free galactose toward the end of kiwifruit maturation on the vine. However, it is difficult to make a comparison, as Ogawa et al. (1990) did not report any fruit characteristics that might allow a realistic comparison with our postharvest ripening results.

The 1988 fruit, which were $25 \pm 0.6 \mathrm{~N}$ at their first sampling at $24 \mathrm{~h}$ after treatment with ethylene, showed a rapid decrease in $\mathrm{PE}$ activity (data not shown). Fruit in 1989 were at $67 \pm 3 \mathrm{~N}$ when first sampled at the end of ethylene treatment and showed a transient increase in salt-extracted PE activity (Fig. 2a)

Significant PE activity was released when the outer pericarp cell wall pellet was digested with fungal enzyme digest mix (Wicker et al., 1988). The digestion of the cell wall was necessary to release residual $\mathrm{PE}$, as washing the cell wall with citrate alone released no PE activity. The digest-released $\mathrm{PE}$ did not show the same increase in response to ethylene (Fig. 2c).

To confirm the trend for a transient increase in the salt-extracted PE activity in response to ethylene, we sampled kiwifruit in 1991 during ethylene treatment. Fruit from the DSIR Research Orchard at Kumeu were harvested at $5.7 \%$ SSC and treated $7 \mathrm{~h}$ after harvest with ethylene at $100 \mu \mathrm{l} \cdot$ liter $^{-1}$ for 15 h. Fruit were sampled by combining plugs taken from the middle third of the outer pericarp of 20 fruit. Fruit firmness for each sample time was determined from a further set of 20 fruit (Table 1). Samples for PE extraction were taken before ethylene treatment, at 3 and $6 \mathrm{~h}$ after the start of treatment, at the end of treatment, and at 2, 5, and 19 days after treatment. A sample of fruit that had not been treated with ethylene was also taken $22 \mathrm{~h}$ after harvest (Table 1).

For fruit harvested in 1991, sodium tetrathionate replaced leupeptin as the actinidin inhibitor (Boland and Hardman, 1972) at concentrations of $10 \mathrm{~mm}$ in the initial homogenisation buffer, $5 \mathrm{~mm}$ in the salt and digestion buffers, and at $2 \mathrm{~mm}$ in the dialysis solution. Extractions were replicated four times. These results showed a similar trend in salt- and digest-extracted PE activity in response to ethylene (Fig. 2 b and d) as in 1989, despite being less mature at harvest (as determined by average SSC). The sample that had not been treated with ethylene had $\mathrm{PE}$ activities similar to those of fruit at har- 
vest and at $3 \mathrm{~h}$ after ethylene treatment (data not shown). Co-extraction of samples with high and low PE activity resulted in rates similar to those of soft fruit for salt-extracted $\mathrm{PE}$, but not for digest-extracted PE activity (data not shown).

The high levels of PE activity extracted from kiwifruit imply that the enzyme is under strict control in vivo. Balestrieri et al. (1990) were unable to measure PE activity in ripe kiwifruit unless they first extracted a potent water-soluble glycoprotein inhibitor of PE activity. Our initial homogenisation buffer included 5\% PEG, which may have prevented removal of sufficient PE inhibitor.

A decrease in PE during softening has been reported for other fruit such as avocados (Awad and Young, 1979) and sweet pepper (Jen and Robinson, 1984). There is some suggestion that exposure to ethylene affects PE activity in bananas (Musa xparadisiaca L.). PE activity decreased in bananas kept in air, but not when kept in the presence of ethylene or under low $\mathrm{O}_{2}$ conditions (Kanellis et al., 1989). Constant levels of PE activity during softening in bananas were also found by Brady (1976) when fruit were kept in the presence of ethylene.

Release of significant PE activity only after digestion of the cell wall with fungal enzymes suggests that there may be a differential association between some forms of PE and the cell wall. Giovane et al. (1990) found differences in glycosylation in salt-extracted PE from kiwifruit based on affinity of binding to heparin-sepharose. Glycosylation may be a factor in the partitioning of PE activity between salt- and digest-extracted fractions.

The activities measured in crude enzyme extracts of kiwifruit ripened in response to ethylene do not show the large scale induction of either PG or $\beta$ - gal we might have expected from studies by others or from the chemical analysis of cell wall changes in kiwifruit. The results for PE activity suggest that the transient increase in activity seen in $\mathrm{PE}$ extracted under high salt conditions, in combination with the de-esterification of pectin found after ethylene treatment (Redgwell et al., 1991), may be a specific response to etheylene exposure rather than part of the usual events of fruit softening.

\section{Literature Cited}

Awad, M. and R.E. Young. 1979. Postharvest variation in cellulase, polygalacturonase, and pectinmethylesterase in avocado (Persea americana Mill, cv. Fuerte) fruits in relation to respiration and ethylene production. Plant Physiol. 64:306-308.

Balestrieri, C., D. Castaldo, A. Giovane, L. Quagliuolo, and L. Servillo. 1990. A glycoprotein inhibitor of pectin methylesterase in kiwifruit (Actinidia chinensis). European J. Biochem. 193:183-187.

Boland, M.J. and M.J. Hardman. 1972. Kinetic studies on the thiol protease from Actinidia chine\&s. Federation of European Biochem. Soc. Lett. 27:282-284.

Brady, C.J. 1976. The pectinesterase of the pulp of the banana fruit. Austral. J. Plant Physiol. 3:163-172.

Fuke, Y. and H. Matsuoka. 1984. Changes in content of pectic substances, ascorbic acid and polyphenols, and activity of pectinesterase in kiwi fruit during growth and ripening after harvest. Nippon Shokuhin Kogyo Gakkaishi 31:3137.

Giovane, A., L. Quagliuolo, D. Castaldo, L. Servillo, and C. Balestrieri. 1990. Pectin methyl esterase from Actinidia chinensis fruits. Phytochemistry 29:2821-2823.

Grierson, D. and G.A. Tucker. 1983. Timing of ethylene and polygalacturonase synthesis in relation to the control of tomato fruit ripening. Planta 157:174-179.

Gross, K.C. 1982. A rapid and sensitive spectrophotometric method for assaying polygalactaronase using 2-cyanoacetamide. HortScience 17:933-934.

Hallett, I.C., E.A. MacRae, and T.F. Wegrzyn. 1992. Changes in kiwifruit cell wall ultrastructure and cell packing during postharvest ripening. Intl. J. Plant Sci. 153:349-60.

Jen, J.J. and M.L. Robinson. 1984. Pectolytic enzymes in sweet bell peppers (Capsicum annuum L.). J. Food Sci. 49:1085-1087.
Kanellis, A.K., T. Solomos, and A.K. Matoo. 1989. Changes in sugars, enzymic activities and acid phosphatase isoenzyme profiles of bananas ripened in air or stored at $2.5 \% \mathrm{O}_{2}$ with and without ethylene. Plant Physiol. 90:251-258.

Lallu, N.. A.N. Searle. and E.A. MacRae. 1989. Investigation into ripening and handling strategies for early season kiwifruit. J. Sci. Food Agr. 47:387-400.

MacRae, E.A.. N. Lallu, A.N. Searle, and J.H. Bowen. 1989. Changes in the composition of kiwifruit (Actinidia deliciosa) affected by maturity at harvest and postharvest treatments. J. Sci. Food Agr. 49:413-430.

Matsui, T. and H. Kitagawa. 1988. Seasonal changes in pectinmethylesterase and polygalacturonase activity in kiwifruit. Nippon Shokuhin Kogyo Gakkaishi 35:851-855.

Ogawa, H., H. Fukumoto, T. Yano, K. Yamamoto. and T. Tochikura. 1990. Purification and characterisation of $\beta$ - galactosidase from kiwifruit. Nippon Shokuhin Kogyo Gakkaishi 37:298305.

Perbal, B. 1988. A practical guide to molecular cloning, p. 47-48. Wiley, New York.

Pressey, R. 1983. $\beta$ - galactosidases in ripening tomatoes. Plant Physiol. 71:132-135.

Redgwell, R.J., L.D. Melton, and D.J. Brasch. 1990. Cell wall chances in kiwifruit following post-harvest ethylene treatment. Phytochemistry 29:399-407.

Redgwell, R.J., L.D. Melton, and D.J. Brasch. 1991. Cell wall dissolution in ripening kiwifruit (Actinidia deliciosa): Solubilisation if the pectic polymers. Plant Physiol. 98:71-81.

Rouse, A.H. and C.D. Atkins. 1955. Pectinesterase and pectin in commercial citrus juices, as determined by methods used at the citrus commercial experimental stations. Bul. Fla. Agr. Expt. Sta., 570.

Soda, I., T. Hasegawa, T. Suzuku, and N. Ogura. 1986. Detection of polygalacturonase in kiwifruit during ripening. Agr. Biol Chem. 50:31913192.

Varoquaux, P., I. Lecendre, F. Varoquaux, and M. Souty. 1990. Change in firmness in kiwifruit after slicing. Sciences des Aliments $1 \& 127-$ 139

Wicker, L., M.R. Vassallo, and E.J. Echeverria. 1988. Solubilization of cell wall bound. thermostable pectinesterase from Valencia orange. J. Food Sci. 53:1171-1174. 